\title{
Tsafon
}

Revue d'études juives du Nord

$76 \mid 2018$

Expressions yiddish de la nature

\section{Carol Iancu, Les mythes fondateurs de l'antisémitisme. De l'Antiquité à nos jours}

Nouvelle édition revue et augmentée, Toulouse, Privat, nov. 2017, 295

pages, $18,50 €$

Danielle Delmaire

\section{(2) OpenEdition}

Journals

Édition électronique

URL : https://journals.openedition.org/tsafon/1510

DOI : $10.4000 /$ tsafon. 1510

ISSN : 2609-6420

Éditeur

Association Jean-Marie Delmaire

Édition imprimée

Date de publication : 1 décembre 2018

Pagination : 185-186

ISSN : 1149-6630

Référence électronique

Danielle Delmaire, «Carol lancu, Les mythes fondateurs de l'antisémitisme. De l'Antiquité à nos jours », Tsafon [En ligne], 76 | 2018, mis en ligne le 26 juin 2019, consulté le 24 juin 2021. URL : http:// journals.openedition.org/tsafon/1510; DOI : https://doi.org/10.4000/tsafon.1510

Ce document a été généré automatiquement le 24 juin 2021.

Tsafon. Revues d'études juives du Nord 


\section{Carol Iancu, Les mythes fondateurs de l'antisémitisme. De l'Antiquité à nos jours}

Nouvelle édition revue et augmentée, Toulouse, Privat, nov. 2017, 295

pages, $18,50 €$

\section{Danielle Delmaire}

\section{RÉFÉRENCE}

Carol Iancu, Les mythes fondateurs de l'antisémitisme. De l'Antiquité à nos jours, nouvelle édition revue et augmentée, Toulouse, Privat, nov. 2017, 295 pages, 18,50€

1 Comme le sous-titre le précise, il s'agit de la réédition de l'ouvrage paru sous le même titre et chez le même éditeur, en 2003. Quinze années se sont donc écoulées et les ajouts concernent essentiellement les événements qui ont agité certains pays européens ainsi que le Moyen-Orient durant ce laps de temps. Et il faut reconnaître que depuis 2003, l'antisémitisme ne s'est guère estompé, il a même gagné en virulence : que l'on songe à Ilan Halimi, Sarah Halimi et Mireille Knoll, assassinés en France parce que juifs, au massacre des enfants de l'école juive de Toulouse et à l'attaque de l'hyper casher ! Une mise à jour n'était donc pas superflue d'autant plus qu'en Tchéquie et en Slovaquie, comme en Roumanie, pays que l'auteur connaît parfaitement, l'antisémitisme n'est pas mort. La postface revient d'ailleurs sur les décennies 2000 et 2010, avec les conséquences en Europe des événements moyen-orientaux comme la seconde Intifada.

Dans les premiers chapitres l'auteur reprend l'ample chronologie de l'antisémitisme qu'il avait brossée dans la première édition, depuis l'Égypte ancienne jusqu'à nos jours, car si le christianisme a nourri, pendant deux millénaires, un antijudaïsme, source d'antisémitisme, l'Égypte ancienne n'est pas exempte d'animosité envers ce petit peuple qui a l'audace de réduire son panthéon à un seul dieu. Les accusations élaborées (déicide, rejet d'Israël, perfidie des juifs etc.) par les premiers chrétiens triomphants à 
partir du IV siècle ont perduré jusqu'à nos jours. Si beaucoup ont été évacuées des doctrines catholiques et protestantes, elles perdurent encore dans certains milieux chrétiens, notamment orthodoxes, et sont reprises par des extrémistes musulmans.

3 L'auteur rappelle les exactions commises durant le Moyen Âge et bien au-delà : expulsions, port de signes distinctifs (dans le monde chrétien et aussi musulman où le situation de dhimmi est plus une contrainte qu'une émancipation), brûlement des textes sacrés, accusation de meurtres rituels (la dernière date du début $\mathrm{du} \mathrm{XX}^{\mathrm{e}}$ siècle) et de profanation d'hostie ou d'empoisonnement des puits, enfin les condamnations au bûcher, ces pages sont une abondante compilation illustrant le martyre du peuple juif durant 2000 ans.

4 L'antisémitisme s'est étoffé au cours des siècles. À l'antijudaïsme religieux antique s'est associé une haine du juif pour des raisons économiques puis raciales pour aboutir à la Shoah du XXe siècle. Cette catastrophe n'a pas mis fin à des croyances sans fondements, se reportant non plus seulement sur les juifs mais sur les Israéliens qui distribueraient des bonbons empoisonnés aux jeunes Palestiniens!

Voilà donc un ouvrage très bien renseigné et qui a l'avantage d'être à la portée du grand public. Sa présence dans les bibliothèques scolaires serait d'un grand secours pour les enseignants qui ont le courage d'aborder un tel sujet, parfois délicat, auprès de leurs élèves. En outre un index des noms de lieux et de personnes facilite la recherche et la lecture. 